\title{
The Nexus of Resident's Participation and Localization of Sustainable Development Goals (SDGs) in Malaysia
}

\author{
Dr. Farah Adilla Abd Rahman ${ }^{1}$, Mohd Idham Mohd Yusof ${ }^{2}$ \\ Faculty of Administrative Science and Policy Studies, Universiti Teknologi MARA (UiTM) ${ }^{1,2}$ \\ Faculty of Forestry and Environment, Universiti Putra Malaysia (UPM) ${ }^{2}$ \\ farah855@uitm.edu.my1,idham708@uitm.edu.my²
}

\begin{abstract}
The Local Agenda 21 (LA21), Millennium Development Goals (MDGs), and Sustainable Development Goals (SDGs) have been the focus of Malaysia's sustainable development initiatives. Its success, particularly in the case of local government as the third level of governance, depended on the active and meaningful participation of its wide range of stakeholders. With the abundance of planning and programs underway, the Ministry of Housing and Local Government (MHLG) has called for the localization of SDGs in the country. It requires political and non-political commitments with its nexus on community participation, especially from the residents at the local level. By referring to the United Nations' (UN) official reports on SDGs progress and Voluntary National Review (VNR), this paper aimed to identify the Malaysian government strategies and efforts towards localization of SDGs and its current progress. Additionally, through qualitative findings, this paper also attempts to discover the residents' participation in supporting the LA21 and SDGs related program implementation at three local governments in Malaysia. The findings showed that the Malaysian government is on the right path in intensifying the SDGs localization, and there are SDGs related programs implemented at the local level. However, further studies need to be conducted to explore its current progress and underlying challenges that hampered an active SDGs localization.
\end{abstract}

Keywords: Sustainable Development Goals, Localization, Residents' Participation

\section{Introduction}

The Malaysian government system is divided into three levels, namely federal, state, and local governments [1], [3], [4]. The symbiotic relationship between the state government with the local government is clearly stipulated in the Federal Constitution. Since the local government is under the purview of the respective state government, the latter has the right to determine the programs and policies that are suitable for the former. The constitutional mechanism is evident with the establishment of the National Council for Local Government (NCLG) to administer, formulate policies, develop and control for the local government.

Since the Earth Summit in Rio de Janeiro, Brazil, in 1992, Malaysia has taken the initiative to support Local Agenda 21 (LA21). It emphasizes the involvement and role of local governments in implementing sustainable development at their territorial jurisdiction. LA21 objectives require local governments to consult with the local community, minority groups, business, and industrial organizations to create a shared vision for future sustainable development and to develop integrated local environmental plans, policies, and programs targeted at achieving sustainable development [5]. In 2015, with the United Nations (UN) commitment towards the Sustainable Development Goals (SDGs), Malaysia was also 
refreshing her pledge towards the Agenda 2030. The SDGs were implemented at the national level, and as stipulated in the Malaysia Voluntary National Review (VNR) for SDGs progress, a similar process will be replicated at the state and local levels. Having sustainable development as its crux, both LA21 and SDGs share similar vision and mission that is to improve the quality of life of the present and future communities.

Localization of the LA21 and SDGs is essential in ensuring both agenda reach the target groups. The local government is seen as a suitable governance entity in intensifying further the sustainability programs to the community at large. Using the bottom-up approach, the creation of resident associations will enable the community to participate with the local government in dealing with local issues that affect their neighborhood. Formed by any group of people living in the same area, the resident association will have autonomy on how it should be governed and administered [6].

Recognized the importance of residents' participation in sustainability initiatives, this paper aims to fulfill two main objectives:

a) To identify Malaysia's government strategies and efforts to localize SDGs and their current progress.

b) To discover the residents' participation in supporting the implementation of LA21 and SDGs related programs in selected local governments.

\section{Literature Review}

This section will review the literature on the localization of SDGs, the concept of resident's participation, and theories involved in the study. Additionally, a few best practices and examples of SDGs localization will also be highlighted for a clear understanding.

\subsection{The Localization of the SDGs}

Localization refers to how the SDGs as a global agenda are manifested at the local level and includes engagement with local governments and other stakeholders at the sub-national level [7]. It is a process of defining, implementing, and monitoring strategies at the local level for achieving global, national, and sub-national sustainable development goals and targets [8]. More specifically, it includes the process of taking into account sub-national contexts in the achievement of the 2030 Agenda, from the setting of goals and targets to determining the means of implementation and using indicators to measure and monitor its progress [8].

The localization of SDGs is part of the evolution of sustainable development governance, which retains the value of top-down and bottom-up initiatives. In order to illustrate the mutually enforceable principle of SDGs as a global-local policy, the term "localization" has now co-existed with "globalization" [9]. This inline with Schwaninger's (2015) concept of sustainability as a recursive process that occurs from the global, national, sub-national, community, and individual levels [10]. Throughout the process, sustainability should exist at all levels and sub-systems of governance, either formal or informal settings, before sustainable development claims to be achieved. To effectively realize these commitments, strong leadership, and decentralization of the SDGs at the local level are needed [9].

At the global level, the Voluntary National Review (VNR) is the voluntary reporting mechanism for tracking the SDGs progress at the individual country's. Under the spectrum of public participation, each country should report to the High-Level Political Forum (HLPF) its current progress for SDGs localization. The activities should be reported together with the 
nationalization of the SDGs, awareness-raising, partnership, institutional arrangements, follow-up, and review mechanisms adopted in the country [7]. The information presented at the HLPF will provide an avenue to share the global best practice and replication of proper implementation among the UN member countries, particularly in SDGs localization. In complementing the VNR, each country's SDGs localization initiatives should be reported in the Local Voluntary Report (LVR). The information reported in LVR will serve as SDGs essential data for national and global reporting.

In carrying out the duty to localize the SDGs, the local governmental authorities will have a critical role in implementing the SDGs and ensuring multi-stakeholders inclusivity. It is understood that each country will have different governmental structures at the local level, i.e., local authorities or local government, provincial or regional government, or municipalities. Whatever the structure would be, the localization of the SDGs is to be carried out by the lowest governmental entity that closest to the community at large. Local government is an entity that familiar with the localities, delivers a wide range of public services, designing a local development plan, and more prone to take integrated approaches in realizing the SDGs. In order to begin these sustainability programs, the local government's initiatives are prerequisites and must include its appointed and elected officials.

As mentioned earlier, the VNR reports should include the respective country's mechanism towards the localization of the SDGs. From the previous VNR submitted to the HLPF, numerous evidence shows that local governments receive support and guidance from the national government to help mobilize resources and ensure policy coherence, particularly in SDGs localization. This support will empower the local governments and have a significant contribution to the SDGs implementation [7]. Data from the review of 2017 and 2018 VNR reports found that 33 countries reported on localization while 30 did so in 2018. Table 1 shows various mechanisms in various countries which include initiatives, institutional arrangements, and capacity to strengthen and intensify SDGs at their local level:

Table 1. SDGs Localization Mechanisms

\begin{tabular}{lll}
\hline Country(s) & \multicolumn{1}{c}{ SDGs Localization Mechanisms } & Source(s) \\
\hline Albania & 1. & Local governments are represented in the Inter-Ministerial [11] \\
Committee on the SDGs. The Albanian Association of \\
Municipalities has been involved in the UNDG SDG-MAPS \\
mission aiming to accelerate the implementation of the SDGs.
\end{tabular}




\begin{tabular}{|c|c|c|}
\hline Indonesia & Indonesia's pilot areas for SDGs (i.e., Riau Province) & [13], [8] \\
\hline Japan & Japan's SDGs Future Cities & {$[13]$} \\
\hline Mexico & $\begin{array}{l}\text { 4. The Office of the President is developing a strategy to help } \\
\text { local governments integrate the SDGs into their policies. } \\
\text { 5. Approximately } 300 \text { municipalities have established committees } \\
\text { for monitoring and implementation of the SDGs (OSIs) } \\
\text { The } 2030 \text { Agenda Executive Implementation Commission } \\
\text { facilitates the implementation of the SDGs at the local level, } \\
\text { and Inter-Institutional Program was introduced to reinforce the } \\
\text { institutional capacity of local governments and provides } \\
\text { technical assistance for the implementation of the SDGs. }\end{array}$ & {$[7],[11]$} \\
\hline South Korea & $\begin{array}{l}\text { Local Councils for Sustainable Development have used a model of } \\
\text { public sector-civil society partnership. These councils are now } \\
\text { supporting the } 2030 \text { Agenda implementation }\end{array}$ & [7] \\
\hline Zimbabwe & $\begin{array}{l}\text { The multi-stakeholders engagement has been concluded through the } \\
\text { successful establishment of the Beyond } 2015 \text { Zimbabwe National } \\
\text { Hub, the building of public-private partnerships, and the launching } \\
\text { of the National Coordination on the Implementation of SDGs } \\
\text { (NACOS Initiative) as efforts towards SDGs localization }\end{array}$ & {$[14]$} \\
\hline
\end{tabular}

The localization of SDGs can begin with the formulation of the Local Plan, which includes the SDGs as its core elements. This local plan will support sustainable development planning and environmental policy formulation at the local level [15]. In Jamaica, for example, five out of its fourteen Municipal Corporations have already developed Local Sustainable Development Plans (LSDPs), which are a vital element of the local adaptation and implementation of the SDGs [11]. As for Indonesia, the Province of Riau was chosen as the pilot project for SDG localization in the country by focusing to SDG1 (no poverty), SDG3 (good health and well being), SDG4 (quality education) and SDG17 (partnership for the goals) [16]. It is not necessarily that the local government has to fulfill all the 17 SDGs in its local implementation. Based on their capacity and strength, the local government may retain or modified the existing national SDGs indicators to suit their local features and local realities [15]. It will encourage and motivate the local government to act on SDGs based on their unique features.

As shown in Table 1, Japan and Indonesia have started to localize the SDGs. However, both countries are facing challenges related to their local governance system [13]. Due to low participation from the local authorities and the absence of SDGs legal framework, Japan needs to intensify further SDGs "vision and objective setting," "strategy development," and "monitoring, evaluation, and review" in their local policy plans and established coordinated bodies featuring multiple stakeholders. As for Indonesia, there is a lack of coordinated systems involving multiple stakeholders and inadequate capacity, experience, resources, and data for implementing and reporting on SDGs activities. Nonetheless, Indonesia has a higher level of "connectivity" concerning "strategy development" than Japan because of the legal framework that aligns local action plans with national and local strategies in Indonesia [3]. To localizing the SDGs, similar and additional challenges may exist in other countries, particularly in Southeast Asia. Lack of financial resources, lack of SDGs expert, and lack of data need to be observed as it might serve as a standard-issue that may affect the localization efforts. As reported by the United Cities and Local Governments (UCLG), the overall SDGs localization in this region is still low, and more need to be done [8]. If the scenario persists, this will hamper the initiative for localization of the SDGs and require aggressive national-level 
support and political commitments in prioritizing SDGs. Similar measures are, therefore, could be replicated from national to the sub-national and local levels.

Overall, the localization of SDGs requires the integration of SDG16 and SDG17 on the participation and partnership of various stakeholders. In line with the SDGs mantra of "leaving no one behind," the initiative for localization of the SDGs should involve the most critical groups of stakeholder, that is the residents of the localities. Continuous engagement and partnership is the only way to bring the vision and mission to reality.

Hence, the discussion on the localization of the SDGs will be incomplete without exposure to the residents' participation. The next subsection will highlight the concept of residents' participation and the theories involved, mainly used in this paper.

\subsection{The Concept of Resident's Participation}

The general concept of participation is decision-making by a number of involved groups [7], and it depends on the issue, timing, and the political setting in which it takes place. The term participation can be traced back to the 1940s and the 1960s when attention was drawn to development studies [18]. However, there is still no single definition of participation that is universally accepted. Various scholars and practitioners give a different meaning of participation [19]. The generic interpretation of participation is active in political decisionmaking. It increases the control of the group and delegates certain decision-making powers to the public [20], [18]. If this group had previously been denied access to resources and regulatory institutions, they are now had control over the decisions taken. This is the activist point of view on participation.

From the perspective of development economists, participation is equal sharing of a project that brings more benefits to the community than to the government. As one of the stakeholders, communities are engaged and play a key role in development initiatives, decisions, and resources [21], [22]. In this context, the local initiative is the best state of participation compare to "resident consultation" and "resident labor input" [23].

\section{Residents' Participation through Residents' Associations}

In localizing the SDGs, the resident association is one of the key stakeholder groups to ensure the success of the initiatives. Membered by the residents living in territorial under the local government jurisdiction, the leadership of the resident association was democratically elected to manage the affairs and issues affected by the local community. As the connector between the local government and the residents, residents' association will act as their member voices. The residents will also participate in local issues affecting their neighborhood, such as the maintenance of the local environment, prevention of crime, anti-social behavior, and housing management.

Various literature has discussed the resident and local government relationships, particularly in environmental function. The residents' associations and the local government has distinct roles in community leadership and brings mutual benefits. It strengthened the community and local government relationships, particularly in participative, interpretative, implementation, deliberative, and community-based planning for sustainable development [24]. In the Malaysian context, a study by Zakaria, Noordin, and Syawal (2010) discovered that residents are satisfied with the environmental functions provided by the local government in the state of Kedah [25]. It meant that both the service provider and the recipient needed a reciprocal relationship to ensure the success of any program in the local context. In the United Kingdom, the role of residents association is essential as they work hand in hand with the local government to solve any issues arising in their local area. The residents association has the 
power to monitor and review the services provided by the local government and, most importantly, become more involved in making choices and decisions affecting their area and any plans that the local government has for the future [26].

However, in most cases, the government has neither been interested in working with the resident association or other state actors [27]. There is an issue of trust between the local government and other stakeholders, especially when the latter is challenging the local government's role in providing essential services and accusing it of being ineffective and corrupt. This will impede the resident's meaningful participation and delaying essential programs that meant for the community at large; in this context is LA21 and SDGs related initiatives.

\subsection{Theories Involved in the study}

Since the central discussion in this study is on the resident's participation, the study in this paper involved two main theories; Arnstein Participation Theory (1969) and Social Exchange Theory.

Arnstein Levels of Participation (1969)

Firstly, this study refers to Arnstein's Levels of Participation to determine the resident's association level of participation. According to Arnstein (1969) (See Figure 2), genuine participation includes a high level of public participation [28]. It is a level in which the public can influence the decision process. There is a difference between participation and gaining influences to affect the outcome of the processes. Arnstein criticized participation that does not influence decision making and policies.

On the other hand, excessive deference to citizens' representatives obstructs agencies' ability to meet social and administrative demands. Arnstein (1969) has arranged eight rungs of participation in a ladder pattern and divided it into three levels. Table 2 explained the three levels of participation, namely non-participation, degrees of tokenism, and degrees of citizen power:

Table 2. Three Levels of Participation According to Arnstein (1969)

\begin{tabular}{|c|c|}
\hline Levels & Explanation \\
\hline $\begin{array}{l}\text { Degrees of Citizen } \\
\text { Power }\end{array}$ & $\begin{array}{l}\text { The steps included in this category are partnership, delegated } \\
\text { power, and citizen control. In this step, the decision-making } \\
\text { authority lies partially or solely with the public. The public can } \\
\text { decide, negotiate, and engage, and can control the issues or } \\
\text { processes involved. }\end{array}$ \\
\hline Degrees of Tokenism & $\begin{array}{l}\text { Public participation is starting to happen at this stage. This level } \\
\text { allows the community to speak and hear. However, this voice } \\
\text { only qualifies solely, with a decision on a matter outside of their } \\
\text { jurisdiction. There are three levels in this stage of informing, } \\
\text { consulting, and placating. At this level, the citizens can advise } \\
\text { the decision-makers but hold no decision-making authority in } \\
\text { their recommendations. }\end{array}$ \\
\hline Non-participation & $\begin{array}{l}\text { It consists of two levels of manipulation and therapy, which is } \\
\text { the lowest level. The goal of these two levels is to allow the } \\
\text { power to influence people, always to obey and accept their views } \\
\text { and insights. The objective of these types of participation is often } \\
\text { to serve as a substitute for genuine participation. The decision- } \\
\text { makers' objective is to educate the public on participation. }\end{array}$ \\
\hline
\end{tabular}




\section{Social Exchange Theory}

Next, this study uses the theory of social exchange to explain the relationship between the residents' association and the local government. Over the last fifteen years, a distinct approach has emerged in sociology, and social psychology called the theory of social exchange [29]. Social exchange theory was one of the major theoretical perspectives of social psychology [30]. George Homans, John Thibaut, Harold Kelley, and Peter Blau are the leading scholars of this theory [29], [31]. According to Emerson (1976), the theory of social exchange is limited to actions that are contingent on rewarding reactions from others [9]. This theoretical orientation is based on earlier philosophical and psychological orientations derived from utilitarianism, on the one hand, and behavioralism, on the other. The remnants of both of these theoretical foundations remain evident in the current versions of the exchange theory [30].

As cited in Cook and Rice (2003), Peter Blau views the social exchange theory from a more economical and utilitarian perspective [30]. Blau defines social exchange as the voluntary actions of individuals motivated by the returns they are expected to and typically do bring from others. People are viewed as acting in terms of anticipated rewards that benefit them, and they tend to choose that alternative course of action that maximizes benefit. Reinforcement theories look backward, with actors valuing what has been rewarded to them in the past. The micro-level exchange theory in Blau's work is embryonic and underdeveloped though it is one of the first attempts to apply utilitarianism derived from economics to social behavior.

Trust concepts are a critical component of the social exchange literature in two primary respects. First, the absence of any formal contract or specified repayment schedule creates a built-in vulnerability, with one party risking the possibility that the other can fail to meet obligations. As a result, social exchange relationships cannot develop in the absence of trust. Several other constructs also have been described as indicators of social exchange relationships, including felt obligation, which reflects the feeling that an individual owes the exchange partner a maximum amount of energy and effort and psychological contract fulfillment, which reflects the degree to which a party perceives that their exchange partner has fulfilled promised obligations. To the extent that trustworthiness predicts outcomes through the mechanisms of affective commitment, felt obligation, psychological contract fulfillment, and so forth, the mediating role of trust is partial. These results suggest that high trustors may be better at building social exchange relationships because they are more prone to adhering to the norm of reciprocity and are more likely to commit to the long-term protection of the exchange relationship. The social exchange theory and the norm of reciprocity stipulate that from the moment that mutually favorable actions are developed, the relationship of exchange will be a lasting one, and the obligations between the parties will be reinforced and respected [32].

\section{Method}

Content analysis and review of the literature was adopted in fulfilling the first objective in this paper. Few SDGs official reports from the Government of Malaysia, UN and its agencies' and United Cities and Local Governments (UCLG) were referred. An analysis was done in discovering the SDGs current localization progress and achievement, particularly in the Malaysian context. 
For the second objective, this study employed a single embedded case study design, as it involves three local councils in one state (State of Selangor). As a qualitative approach, this study aims to explore attitudes, behavior, and experiences through face to face, semistructured interviews, and Focus Groups Discussion (FGD) to gain in-depth and rich data from the selected participants. The method was chosen to allow the participants to have freedom of expression in response to the subject matter that was discussed. In conducting the interview and FGD, few procedures were observed. Firstly, information regarding active resident associations was obtained from the respective local government. Second, contact the chairman of the resident associations and arranging the first interview for data collection. Finally, using a snowballing technique, more participants contact number was obtained for the FGD to be conducted. Table 3 shows the detail of the participants involved in the study. A total of 30 participants were involved in the study, encompassing the resident association at Shah Alam City Council (ACC), Subang Jaya Municipal Council (SJMC) and the Kuala Selangor District Council (KSDC). As a purposive sampling, the participants at the three localities were selected based on specific criteria; a) actively participate in the resident association, b) local citizens, and c) years of staying in that area.

There are a few things that are taken into account during the interview and the FGD session. This includes the participant consent and language used to ensure the ethical considerations are being observed throughout the data collection process. When the authors are satisfied that the data has reached its saturation point, the data were analyzed thematically. After undergoing data transcription and manual coding, the data are arranged into themes and sub-themes for the authors identifying the pattern of the participant's data.

Table 3. Details of participants involved in the study

\begin{tabular}{|c|c|c|c|}
\hline Local Councils & Resident Associations & $\begin{array}{l}\text { Number of } \\
\text { Participants }\end{array}$ & Language Used \\
\hline $\begin{array}{l}\text { Shah Alam City Council } \\
\text { (SACC) }\end{array}$ & $\begin{array}{l}\text { Flat Nilam Sari Residents' } \\
\text { Association }\end{array}$ & 8 & Bahasa Malaysia \\
\hline $\begin{array}{l}\text { Subang Jaya Municipal } \\
\text { Council (SJMC) }\end{array}$ & $\begin{array}{l}\text { Laman Putra Residents' } \\
\text { Association (LPRA) }\end{array}$ & 9 & English \\
\hline $\begin{array}{l}\text { Kuala Selangor District } \\
\text { Council (KSDC) }\end{array}$ & $\begin{array}{l}\text { Taman Seri Tanjong } \\
\text { Residents' Association }\end{array}$ & 13 & Bahasa Malaysia \\
\hline
\end{tabular}

\section{Result And Discussion}

In this section, the discussion on the findings of the study and will be arranged in accordance with the research objectives. The first objective of the study will discuss findings from the content analysis of reports and review of literature, while the second objective will discuss qualitative findings from the interview.

\subsection{First Objective: To Identify Malaysia's Government Strategies and Efforts to Localize SDGs and their Current Progress.}

The Eleventh Malaysia Plan and the Shared Prosperity Vision 2030 (SPV) are synchronized with the SDGs aspirations by virtue to ensure the country will be an advanced economy and inclusive nation. In supporting these long term Malaysia Plan, the national annual budget is allocated to materialize the SDGs various initiatives and programs 
undertaken by numerous ministries and its agencies. While addressing the people's core needs in its journey for the nation's development and growth, the SDGs in Malaysia have been further localized and mainstreamed through its National SDG framework.

Various strategies have been adopted in localizing the SDGs in the country. The first is to have an institutional arrangement at the national level as portrayed in Figure 1. The SDG governance structure in Malaysia was led by the National SDG council chaired by the Prime Minister. In assisting the National SDG Council, the Steering Committee chaired by the Director-General of the Economic Planning Unit (EPU) and membered by five working clusters and have taskforce representing all the 17 SDGs. In ensuring the inclusivity, various stakeholders are engaged in the working committee and the taskforce to mobilize the SDGs implementation and for data sharing. This institutional arrangement is to ensure the multipartnership and coordination could be undertaken at various levels, mainly to localize the SDGs. Malaysia's commitment is apparent as the country adopting a whole-of-nation approach in attaining the SDGs.

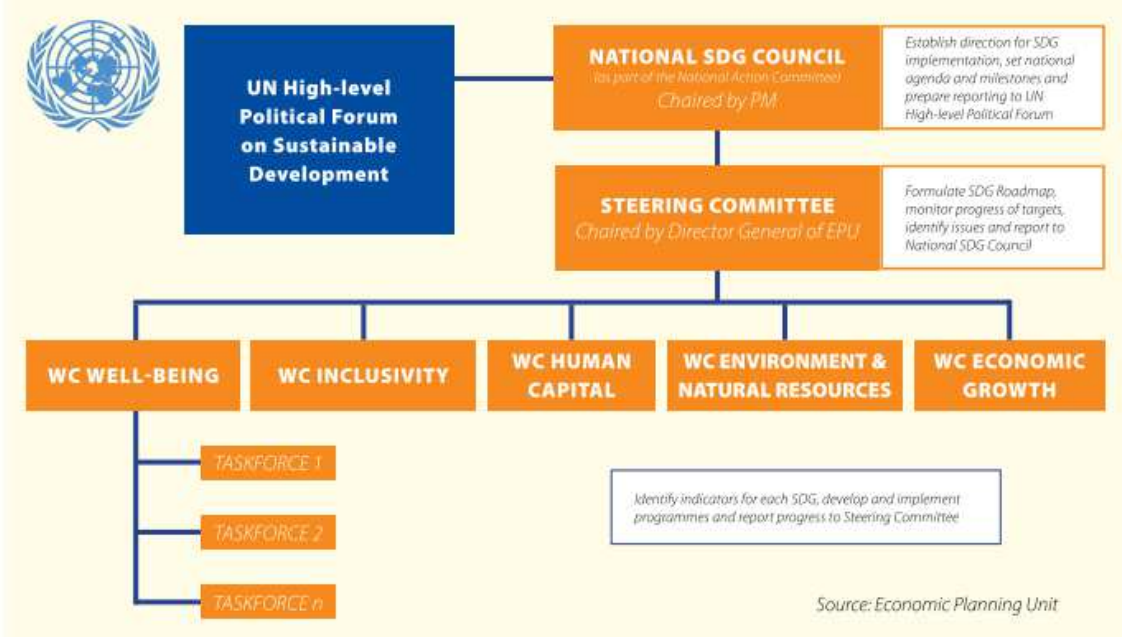

Fig.1. The SDG Governance Structure in Malaysia [33]

Second is by collaborated with various international and national agencies. The United Nations Country Team (UNCT) is working closely with the Economic Planning Unit (EPU) in mainstreaming and localizing the SDGs at the state and local levels. The Multistakeholder Partnership Conference for implementation of the 2030 Agenda is one of the earlier programs organized by the UNCT and EPU to localize the SDGs in the country [33. The UNCT also has proposed various strategies to the government to accelerate the efforts of SDGs localization in the country, which include mobilization of multi-stakeholders partnership, SDGs ownership, and strengthening the data readiness and preparedness [34]. In reaching further the grassroots, the CSO-SDG Alliance was established in 2015 to support the government in its SDGs efforts. The Alliance membership is national Non-Governmental Organizations (NGOs) and Civil Society Organizations (CSOs) from different categories to enable and strengthening the localization of the SDGs. Their significant role is evident as the CSO-SDG Alliance is among the members in the cluster and taskforce under the National SDG Steering Committee [35]. 
Despite visible SDGs governance at the national level, SDG discussions at the state and local government levels are almost non-existent [33]. There is also limited empirical evidence from past literature and in official reports regarding Malaysia's progress in SDGs localization. Hence, more discussion and reporting on the SDGs localization accomplishment in the country is needed. As proposed by literature on SDGs and UCLG reports, localization of the SDGs at the sub-national level and local level is pertinent to ensure its effective implementation and to support the national progress and reporting measures. In the Malaysian context, even though SDGs is a voluntary commitment, this 2030 Agenda must be localized to state levels since the states will be implementing development plans, and it will further motivate the local level to do the same. At present, Penang is the most visible state in the country to have the development blueprint that was mapping with the SDGs, known as Penang 2030. In realizing the need to localize SDGs at the local level, the Ministry of Housing and Local Government, together with URBANICE has started its efforts to encourage the local government in Malaysia to prepare its VLR and align it with SDGs. The call for it was done during the Asia Pacific Urban Forum (APUF) 2019 in Penang, and Seberang Prai City Council (a local government in the state of Penang) is pioneering the Voluntary Local Review in 2019 that mapped its local government program with SDGs. The other state and local government in Malaysia should replicate this best practice, as most of the local government in the country is still attached to LA21 and has not moved forward in aligning its activities with the SDGs.

\subsection{Second Objective: To Discover the Residents' Participation in Supporting The Implementation of LA21 And SDGs Related Programs in Selected Local Governments.}

\section{Mapping the LA21 Programs with the SDGs}

From the interview with thirty participants, seventeen had participated in LA21, whereas thirteen of them have not participated in programs or activities related to LA21. The majority of residents were actively involved in various planning or activities conducted either by their local government or by their neighborhood initiatives. The three types of programs organized by the local government and participated by the residents are; health awareness program, recycling program, cleanliness of the surrounding area, and safety program. All of the residents who lived in the city and municipal council areas participated in LA21, compared to none in the district area (Taman Seri Tanjong). This is due to the non-implementation of LA21 in the area. The only programs that involved the residents are the cleanliness and awarenessraising programs initiated by the residents association.

An interview with the Shah Alam City Council (SACC) officer stated that resident participation in the local government is exceptionally imperative. Residents' participation in LA21 programs has brought benefits to SACC in the form that it saves some of the City Council funds and generates more revenue. For example, the residents would help clean up and beautify their neighborhood in the "save the environment" program. This has consequently reduced the local government's burden because of their lack of staff and funds to maintain a cleaner environment. Additionally, as far as the recycling program is concerned, it will promote sustainable development for the residents and generate thousands of ringgit for the council from its activities. Consequently, the environmental awareness among residents is improving, and this encourages them to make wise use of the public facilities provided by SACC.

Overall, from the qualitative data, there is partnership and participation between the residents and the local government in LA21 programs. In the SDGs context, it fulfilled 
SDG16 (participation) and SDG17 (partnership) at the three local authorities, as there is a bottom-up and top-down approach in the SDGs implementation. There is also localization of SDGs related programs at these three local governments that fulfill SDG3, SDG11, and SDG12, and it can be seen from Table 4.

Table 4. Mapping of LA21 Programs with SDGs

\begin{tabular}{ll}
\hline \multicolumn{1}{c}{ LA21 Programs } & \multicolumn{1}{c}{ SDGs } \\
\hline Health Awareness & $\begin{array}{l}\text { SDG3 } \\
\text { (Good Health and Well-Being) }\end{array}$ \\
Safety Programs & $\begin{array}{l}\text { SDG11 } \\
\text { (Sustainable Cities and Communities) }\end{array}$ \\
Recycling and Cleanliness Programs & $\begin{array}{l}\text { SDG12 } \\
\text { (Responsible Consumption and Production) }\end{array}$ \\
\hline
\end{tabular}

Residents Participation in LA21 Programs based on the Social Exchange Theory

Findings from this study also met the principles, as highlighted in the social exchange theory. There is a general expectation of some future return when one person does another as a favor. However, this behavior must be oriented toward the end and can only be achieved through interaction with other persons [30]. Based on the findings, the majority of residents have participated in LA21 programs and are currently still participating, whether initiated by the local government or by a resident association. The residents are continuously trying to improve the conditions, cleanliness, and safety of their neighborhood area.

Their voluntary participation in LA21 programs is due to several factors. First is that residents are aware of their responsibility to maintain their place of living. Participants understood that their participation in clean-up, awareness-raising programs, and recycling activities have a positive impact on their lives, mainly to ensure that they lived in better conditions and environments. Second, their tenure of staying has enabled the residents to recognize the environmental problems that they are facing and what actions would best be taken. The third is their trust in the local government. Finally, the unique culture in the neighborhood has increased their confidence, experience, and skills to participate. They are also very dedicated and hardworking and had consistently contributed to their community. Consequently, participants have a great time bonding with each other.

Overall, the residents' participation in LA21 has improving their living conditions, maintaining sustainable development in their local area, and also improving the quality of life. This is in line with the social exchange theory, which stipulates that when mutually favorable actions are developed, the relationship between the parties was reinforced and respected [32].

Level of Residents Participation in LA21 Programs

According to Arnstein (1969), genuine participation includes a high level of public participation. Arnstein had arranged eight rungs of participation in a ladder pattern and divided it into three levels, which were non-participation, degrees of tokenism, and degrees of citizen power. From Figure 2, this study had discovered that the resident's participation in LA21 and SDGs related programs at the three local governments was at the non-participation and degrees of the tokenism level. The non-participation level consists of two levels, which are manipulation and therapy, and it is the lowest level in the ladder pattern. The goal of these two levels is to influence people, for them to obey and accept government views and insights. In this level, the decision-makers' objective is to educate the public on their participation. The local government encourages residents to participate, not only for the sake of themselves but also for the benefit of the local government. Lack of staff and the need to reduce the cost of managing the area can be addressed through the participation of residents in activities and 
programs such as recycling, cleanliness, and awareness-raising. The programs and activities that residents had participated in were only considered to assist the local government work. Besides, most of the decisions made by the local government were without involving the residents. At the degrees of tokenism level, residents at the three local governments are allowed to voice up their opinion and listen. At this level, the residents also can advise the decision-makers but have no decision-making authority in their recommendations. Though residents can raise issues or give opinions in the meeting, the residents still have to follow the decision made by the local government.

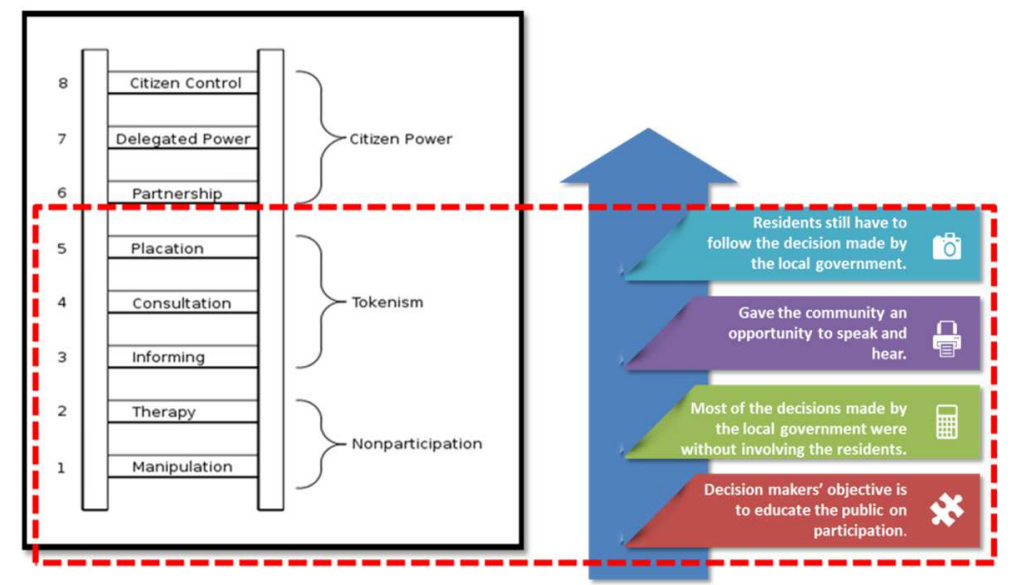

Fig.2. The Level of Resident Participation in this Study based on Arnstein (1969)

\section{Conclusion}

The participation of the residents in the local government programs such as recycling and cleanliness programs are essential for the local government. Residents' participation can help the local government to save money and time, especially when the local government is short of staff and funds in maintaining a cleaner living area. Moreover, the participation of the residents can promote sustainable development in their local area and create awareness among themselves when using public facilities. Hence, it is more beneficial for the local government as residents' participation helps it to manage the local area better. Besides, the resident actively involves the activities or program, whether it is initiated by the local government or by them, thus indicated that the local government must always encourage the residents to participate primarily in the environmental program.

There should be an increase in the level of participation of the residents. The roles of the residents are essential as decisions made by the local government will positively affect them living in a particular area. Hence, the power to make decision-making should be given to the residents. The public can decide, negotiate, and engage, and can control the issues or processes involved. The social exchange theory stressed that people make calculations about the resources they give to and receive from the exchange partner, and compare their treatment to referent others to gauge whether the social exchange is mutual or equitable. For that reason, the local government should increase the level of trust of residents toward them. Distrust could decrease the motivation of residents' participation in the future. 
In conclusion, there are initiatives to localize SDGs in Malaysia through various mechanisms. However, more active engagement with residents and institutionalization of the programs is needed. VLR should be made compulsory to all local governments as it will assist the government in VNR reporting. Consequently, Malaysia will have a better SDGs ranking at regional and global levels. More studies are also needed to be conducted to further explore on SDGs current progress and its underlying challenges that delayed an active localization.

\section{Acknowledgments}

The author would like to thank the staff and resident's association at the Shah Alam City Council (SACC), Subang Jaya Municipal Council (SJMC), and the Kuala Selangor District Council (KSDC) for providing the facilities and assistance for this study. Authors also would like to express their gratitude and appreciation to the Faculty of Administrative Science and Policy Studies (FSPPP), Universiti Teknologi MARA (UiTM), for the funding of this paper.

\section{References}

[1] Ahmad Atory H. Local Government: Theory and Practice in Malaysia. Kuala Lumpur: Dewan Bahasa dan Pustaka; 2002.

[2] Zahari AR. Understanding Local Government in Malaysia. Petaling Jaya: Penerbit Fajar Bakti Sdn. Bhd; 1991. 1991 p.

[3] Phang SN. Local Government System in Malaysia. Kuala Lumpur: Dewan Bahasa dan Pustaka; 1996.

[4] Malaysian Federal Constitution. Kuala Lumpur: International Law Book Services; 1999.

[5] Sustainable Development Features [Internet]. 2020. Available from: https://www.gdrc.org/sustdev/concepts/18-la21.html

[6] Government E. Ealing Council Resident and Community Association Governance Manual [Internet]. Available from: https://www.ealing.gov.uk/ info/201090/get involved/435/resident associations/1

[7] UNDESA. Multi-stakeholder engagement in 2030 Agenda implementation: A review of Voluntary National Review Reports (2016-2019).

[8] UCLG. Towards the localization of the SDGs. Local and regional governments' report to the 2019 HLPF: 3rd Report [Internet]. 2019. Available from: https://www.uclg.org/sites/default/files/towards_the_localization_of_the_sdgs_0.pdf

[9] Meuleman L, Niestroy I. Common but differentiated governance: A metagovernance approach to make the SDGs work. Sustainability. 2015;7(9):12295-321.

[10] Schwaninger M. Organizing for sustainability: a cybernetic concept for sustainable renewal. Kybernetes. 2015;44(6-7):935-54.

[11] UNDESA (Department for Economic and Social Affairs). Compendium of National Institutional Arrangements for implementing the 2030 Agenda for Sustainable Development [Internet]. 2019. Available from: http://workspace.unpan.org/sites/Internet/Documents/UNPAN97468.pdf

[12] UNDESA. World Youth Report: Youth and the 2030 Agenda for Sustainable Development World [Internet]. New York; 2018. Available from: https://www.un.org/development/desa/youth/wpcontent/uploads/sites/21/2018/12/WorldYouthReport-2030Agenda.pdf

[13] Morita K, Okitasari M, Masuda H. Analysis of national and local governance systems to achieve the sustainable development goals: case studies of Japan and Indonesia. Sustain Sci 
[Internet]. 2020;15(1):179-202. Available from: https://doi.org/10.1007/s11625-019-00739-z

[14] UNDESA. Partnerships for SDG. 2015.

[15] Wang Y, Du M, Zhou L, Cai G, Bai Y. A novel evaluation approach of county-level city disaster resilience and urban environmental cleanliness based on SDG11 and Deqing County's situation. Sustainability. 2019;11(20):1-13.

[16] UN. Sustainable Development Goals Partnership Platform [Internet]. 2020 [cited 2020 Aug 12]. Available from: https://sustainabledevelopment.un.org/partnerships/

[17] Sanoff H. Community Participation in Riverfront Development. CoDesign. 2005 Mar;1(1):6178.

[18] Toan DN. Participation in Development : A case study on local participation in rural water supply and sanitation in Vietnam. Asian J Agric Rural Dev. 2012;2(3):1-25.

[19] Paul S. Community Participation in Development Projects. World Bank, Washington DC. Washington DC; 1987.

[20] Goulet, D., \& Dame N. Participation in Development: New Avenues, [Internet]. Vol. 17. 1989. 165-178 p. Available from: https://www.unhcr.org/publications/manuals/4d9352319/unhcrprotection-training-manual-european-border-entry-officials-2-legal.html?query=excom 1989

[21] Kelly D. Community participation in rangeland management: A report for the Rural Industries Research and Development Corporation [Internet]. 2001. Available from: Rural Industries Research and Development Corporation

[22] Mathekga, R., \& Buccus I. The challenge of local government structures in South Africa: Securing Community Participation. Crit dialogue-Public Particip Rev IDASA. 2006;11-7.

[23] Tonami A, Mori A. Sustainable development in Thailand: Lessons from implementing local agenda 21 in three cities. J Environ Dev. 2007;16(3):269-89.

[24] Department of the Environment Community and Local Government. Working Group Report on Citizen Engagement with Local Government . 2014.

[25] Ngah, K., Zakaria, Z., Noordin, N., \& Yaacob MA. The future challenges of local authorities in Malaysia: A case study in Seberang Perai, Penang. African J Bus Manag. 2011;5(26):10841-5.

[26] Council C. Setting up a Residents' Group. [Internet]. 2017. Available from: https://www.croydon.gov.uk/sites/default/files/articles/downloads/residents-group14.pdf

[27] Muthee MW. Urban Resident's Associations and the Management of Services in Nairobi: A Study of the Karen and Langata District Association (KLDA) [Internet]. University of Nairobi; 2003. Available from:

http://erepository.uonbi.ac.ke/bitstream/handle/11295/25224/Muthee_Urban Resident s Associations and the Management of Services in Nairobi A Study of the Karen and Langata District Association(KLDA).pdf?sequence=3

[28] Arnstein SR. A Ladder Of Citizen Participation. J Am Inst Plann [Internet]. 1969;35(4):216-24. Available from: http://repositorio.unan.edu.ni/2986/1/5624.pdf

[29] Emerson RM. Social exchange theory. Annu Rev Sociol. 1976;2:335-62.

[30] Cook, K. S., \& Rice E. Social Exchange Theory in Handbook of Social Psychology. New York: Kluwer Academic/Plenum Publishers.; 2003.

[31] Searle M. Social Exchange Theory as a Framework for Understanding Ceasing Participation in Organized Leisure Activities. In B. . Smale (Ed.). Sixth Canadian Congress on Leisure Research. Ontario Research Council on Leisure; 1990. 1-5 p.

[32] Didier V, C. HM, El Akremi A. The Relationship Between Members`s Trust and Participation in the Governance of Cooperatives : The Role of Organizational Commitment. International. Int Food Agribus Manag Rev. 2012;15(1):1-24.

[33] Malaysia Sustainable Development Goals Voluntary National Review 2017. Economic Planning Unit. 2017.

[34] Malaysia United Nations Sustainable Development Goals Framework 2018-2020 (Draft). 2020.

[35] Khoo YH, Tan LI. Localization of the Sustainable Development Goals (SDGs): Civil Society Organizations' (CSOs) Strategies and Challenges in Malaysia. Asian Dev Perspect [Internet]. 2019;10(2):149-58. Available from: https://umexpert.um.edu.my/public_view.php?type=publication\&row=OTA4NTY\%3D 